\section{African wildlife}

Picture BoOKS about African wild animals suffer a population explosion inversely proportional to the decline in the populations of their subjects. All the arts and crafts of photography and book design combine in sharpening their competition for dominance in the face of the selective pressure of the bookshop browser, who is himself in danger of being bewildered by the plethora of jostling titles.

Some books are the outcome of scientific studies on the lives of various large animals, and are valuable contributions to knowledge made by naturalists who, surprisingly, seem now to prefer being called ecologists, ethologists, and so on, as a fancied boost to their dignity-Linnaeus, Gilbert White, Darwin, Wallace, Bates and the other giants of the past needed no such props.

Most of the books, however, are essentially picture books, of ten of the highest photographic standard, showing the beauties of tropical scenery and animal life. They concentrate on the eye-catching and spectacular parts of the flora and fauna, but give little information about them beyond the "visual display".

The third class is that of the doomsters bewailing the fact that the frontiers of the wilderness are steadily receding in the face of ever-growing human occupation and development of the land. Much as the loss may be deplored, it is a fact that will not go away; wildlife is rapidly becoming confined to reserves and parks which, as time goes on, will become more and more artificial under management and conservation. Only those species such as the jackal in South Africa, and the fox and badger but not the otter in Great Britain, that can survive persecution by man, will remain as wild animals. Even now the average package tourist, conducted to viewing points, and sheltered in hotels or lodges with all European amenities so that he is protected from any close contact with the wild, sees little more than he does in a 'Safari Park' at home only the scale is larger. The very word 'safari', used by the exploiters to beguile him with romantic overtones, merely means a caravan of beasts of burden, or a journey.

The White Lions of Timbavati, by Chris McBride (Paddington: London, 1977; $£ 5.95$ ) is the by-product of a scientific study on the lives of a group of lions that McBride kept under observation for about a year in a large private nature reserve in the north-eastern Transvaal. The group consisted of two dominant males sharing half a dozen lionesses accompanied by their cubs and adolescent offspring. One of the lionesses produced a couple of white, but not albino, cubs, on whose birth and early life the story concentrates. Later, another white cub was born to a different lioness, and the author thinks the white births were a result of the frequent matings between father and daughter or granddaughter, so that homozygotes for the recessive white gene appeared. The white cubs were handicapped by their lack of concealing colouration, and probably survived only because $\mathrm{McBride}$ provided them with food at critical times. His book tells of his adventures with his wife and small daughter living in a bush camp while studying the lions, and makes an excellent read. He has a pleasant straightforward style of writing, and in addition to his narrative he sets out his common-sense thoughts on wildlife conservation and management.

Savage Paradise, by Hugo van Lawick (Collins: London, 1977; $£ 13.95$ ), is a picture book. Van Lawick claims to be a

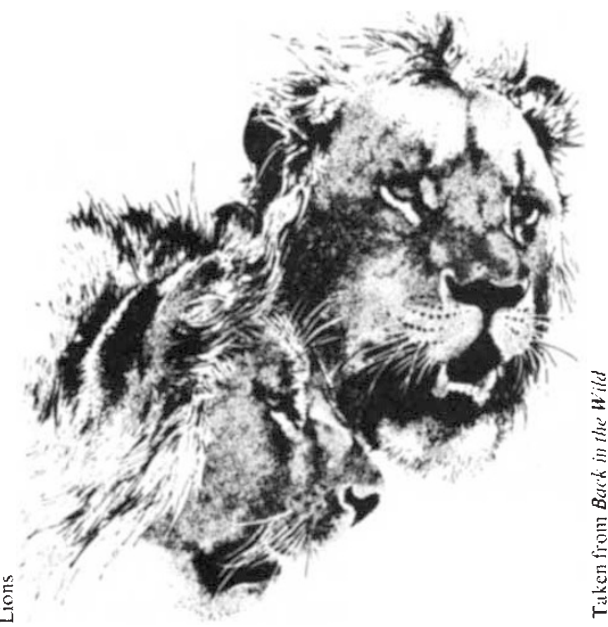

cameraman first and only secondarily a naturalist. His large coloured photographs, up to 20 by 14 inches in size, illustrating the lives of the predatory animals of the Serengeti plains and their prey, are unsurpassed in subject and composition. The author hopes that his pictures will reflect his love for the Serengeti and the Ngorongoro Crater; "but in an honest way, for with its beauty there is also harshness, a savage struggle to survive in a paradise." Savage indeed is the picture of half a dozen hyaenas tearing out the entrails of a living zebra; in spite of the zebra's facial expression, the author assures us that "it is doubtful if the prey feels much pain", a thought that may comfort him if he ever finds himself in a similar predicament. $\mathrm{He}$ prefaces his book with informative essays on each of his subjects-lions, leopards, cheetahs, hyaenas, jackals, and wild dogs- detailing his experiences with each species and "some of the remarkable things that happened while I was watching them." This is a superb book of its class.

Pyramids of Life, by John Reader and Harvey Croze (Collins: London; Leppin-

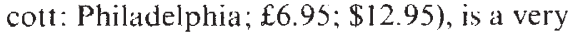
different book. Although every page is adorned with splendid photographs taken by Reader, the pictures are chosen to illustrate the text of each 'double spread' by Croze. The main theme of the book is the circular movement of energy through each ecosystem, the cycle starting with the soil recelving sunlight, water and air to produce plants that are eaten by herbivores which in turn are eaten by the carnivores at the top of the pyramid. At any point in the ascent from primary producer to carnivore, the organisms may die, whereupon their bodies are reduced by mostly microscopic decomposers into simpler substances which return to the soil for the start of another cycle. All this may seem obvious enough, but the infinitely varied paths that the cycle can take, and the inter-relationships of the plants and animals concerned, as described and pictured here, will be a revelation to the intelligent layman who prefers to understand something of what he sees rather than merely making it the subject of holiday snapshots. In the epilogue, Croze points out how knowledge of the way the amounts of energy and materials determine the number of animal and plant pipelines, up through the pyramid of life and back down to the soil, can be used to preserve the richness and yield of terrestrial ecosystems; and that we should not be discouraged by the notion that natural beauty is not its own excuse for existence. More care in editing the book would have avoided such a solecism as 'an algae is', repeated twice.

In Noah's Aik is Stranded, by Björn Berglund (Macdonald and Jane's, 1977; 66.95), the author claims to deliver the "message of African ecology". Berglund is a Swedish journalist who wrote his book after visiting nine East African national parks, where he was shown all the usual sights. The accuracy of his observations on animals may be judged by the double-page photograph of a crocodile walking in a manner exactly the opposite to that stated in the caption. The author seems to suffer from the typical Swedish guilty conscience, for throughout his book he gives the main emphasis to bemoaning man's destructive impact on his environment in Africa. He tells us that "ecology teaches the dependence of the living organism upon the environment and their harmonious interaction", and concludes with a glimpse of the obvious in the admonition that "we must accept that we function within an environment", asking: "are we able to live in harmony with each other and our environment?". He need not look far for the answer.

Back in the Wild, by Sue Hart (Collins: London, $1977 ; £ 5.50)$, is a collection of short articles reprinted from a South African newspaper. Most of them are about conducted visits to various parks and reserves, where the author seems to have looked on the larger members of the fauna as people dressed up in animal skins. The articles are so slight, superficial, and often inaccurate as to fact, that one well may wonder why a publisher should bother to reprint them. The drawings by Mrs Leigh Voigt are better than the text.

L. Harrison Matthews

L. Harrison Matthens was Scientific Director of the Zoological Society of London from 1952-66. 